\title{
PERAN LEMBAGA SWADAYA MASYARAKAT TERHADAP PROGRAM PENGELOLAAN HUTAN BERBASIS MASYARAKAT DALAM KONTEKS PEMBANGUNAN DAERAH
}

\author{
The Role of Non-Governmental Organizations in Community-Based Forest Management Program in \\ Regional Development Contexts
}

\author{
Wahyu Fathurrahman Riva 1, Parulian Hutagaol 2, dan Patrice Levang ${ }^{3}$ \\ ${ }^{1}$ Staff Bagian Sertifikasi dan Akreditasi Lembaga Ekolabel Indonesia (LEI). E-mail: wahyuriva@ideas- \\ consultant.com \\ 2 Staff Pengajar Departemen Ilmu Ekonomi. Fakultas Ekonomi dan Manajemen - IPB. \\ E-mail: parulian_gaol@yahoo.com \\ ${ }^{3}$ Center for International Forestry Research - CIFOR. E-mail: p.levang@cgiar.org
}

\begin{abstract}
The increasing rate of forest degradation and lack of local communities' access to forest, have been a significant stimulus for the implementation of community-based forest management (CBFM). This study aims to assess and analyze the role of $N G O s$ in the implementation of the CBFM program and formulate strategies to improve the role of NGOs in the implementation of the CBFM program. This study use two methods of analysis, which are analyzes the performance of NGOs in the CBFM program and analysis of the institutional development of local institutions. The results of this study, are: 1) Most of NGos (5 NGOs) have good performance in the implementation of the CBFM program funded by UNDP and 2 NGOs have good performance and less well. 2) Development of local institutions influenced by local resource conditions, international, national, and local political-economic factors, and local socio-political factors. 3) The strategy to increase the role of NGOs in the implementation of CBFM in the context of regional development can be done through several ways, are: development in institutional capacity of NGOs, development in empowerment and institutional capacity of community, development in advocacy of local government, development in business of community with the private sector.
\end{abstract}

Keywords: Community-Based Forest Management, Non-Governmental Organizations, Strategy

\begin{abstract}
ABSTRAK
Tingkat kerusakan hutan yang cenderung meningkat dan melemahnya kapasitas masyarakat sekitar hutan akibat kebijakan pemerintah dalam pengelolaan hutan telah memicu munculnya paradigma baru yaitu pengelolaan hutan berbasis masyarakat (PHBM). Penelitian ini bertujuan untuk mengkaji dan menganalisis peran LSM dalam pelaksanaan program PHBM serta merumuskan strategi peningkatan peran LSM dalam pelaksanaan program PHBM. Penelitian ini menggunakan dua metode analisis, yaitu analisis kinerja LSM dalam program PHBM dan analisis pengembangan kelembagaan institusi lokal. Hasil penelitian ini menyimpulkan beberapa hal, yaitu: 1) Sebagian besar (5 LSM) mempunyai kinerja yang baik dalam pelaksanaan program PHBM yang didanai UNDP dan sebanyak dua LSM masing-masing memiliki kinerja yang cukup baik dan kurang baik. 2) Pengembangan institusi lokal dipengaruhi oleh faktor kondisi sumberdaya lokal, faktor ekonomi-politik internasional, nasional dan lokal, serta faktor sosial-politik lokal. 3) Strategi peningkatan peran LSM dalam pelaksanaan PHBM dalam konteks pembangunan daerah dapat dilakukan melalui beberapa hal, yaitu pengembangan kapasitas dan kelembagaan LSM, pengembangan pemberdayaan kapasitas dan kelembagaan masyarakat, pengembangan advokasi pada pemerintah daerah, dan pengembangan usaha masyarakat bersama pihak swasta.
\end{abstract}

Kata kunci: Pengelolaan Hutan Berbasis Masyarakat, Lembaga Swadaya Masyarakat, Strategi

Wahyu Fathurrahman Riva, Parulian Hutagaol,

dan Patrice Levang
Peran Lembaga Swadaya Masyarakat Terhadap Program Pengelolaan Hutan Berbasis Masyarakat dalam Konteks Pembangunan Daerah 


\section{PENDAHULUAN}

\section{Latar Belakang}

Menurut Brown (2004), masyarakat yang tinggal di dalam dan di sekitar hutan di luar Pulau Jawa sekitar 48,8 juta orang. Dari jumlah itu, 10, 2 juta orang miskin (Sunderlin, 2000) tinggal dan hidup di sekitar hutan alam serta sekitar 6 juta kepala keluarga telah melakukan perladangan bergilir secara turun temurun.

Banyak masyarakat yang hidup secara tradisional dengan menerapkan strategi ekonomi melalui kombinasi antara kegiatan berladang untuk mendapatkan padi, menanam tanaman palawija, berburu, memanen dan menjual kayu, mengumpulkan dan menjual hasil hutan bukan kayu (non timber forest products) seperti rotan, madu, dan getah. Hasil dari kebun karet, kopi, dan tanaman lainnya juga penting sebagai sumber pendapatan masyarakat (FWI/GFW, 2001).

Disisi lain, kegiatan penebangan hutan di Indonesia yang tidak terkendali selama puluhan tahun dan menyebabkan terjadinya penyusutan hutan tropis secara besar-besaran. Berdasarkan data terbaru dari Departemen Kehutanan (2007), ratarata laju kerusakan hutan dalam 5 tahun terakhir sebesar 1.089.500 ha/tahun.

Beberapa tahun terakhir telah terjadi perubahan paradigma pengelolaan hutan yang dilakukan oleh masyarakat. Pengelolaan Hutan Berbasis Masyarakat (PHBM/community-based forest management) menjadi salah satu pilihan dalam sebuah sistem pengelolaan hutan yang dilakukan oleh masyarakat. Seiring dengan perubahan tersebut, banyak LSM yang terlibat aktif dan intensif dalam mendampingi masyarakat menuju PHBM. Pengembangan kapasitas dan penguatan kelembagaan masyarakat di sekitar hutan telah menjadi agenda utama dari banyak LSM Kehutanan.

Malik (2004) mencatat bahwa pada mengalami puncak perkembangannya yang berjumlah 13.500. Menurut Ibrahim (2004), jumlah LSM sebagai komponen yang paling visible dan vocal dari Organisasi Masyarakat Sipil (OMS) yang hanya beberapa ribu, di masa Orde Baru telah meningkat menjadi puluhan ribu. Kehadiran LSM di Indonesia, menurut Culla (2006), dipicu oleh faktor kesempatan politik dan beroperasinya lembaga-lembaga donor internasional yang menjadi pendorong lahirnya banyak LSM, juga disebabkan oleh kekecewaan sebagian tokoh/pemimpin terhadap pemerintah yang menunjukkan indikasi penyimpang dari komitmen awal untuk membangun tatanan masyarakat berkeadilan dan demokratis lebih baik ketimbang era sebelumnya.

Tumbuh dan menjamurnya LSM di era Reformasi merupakan fenomena yang menarik untuk dicermati. Menurut Abidin (2004a), pertumbuhan LSM itu di satu sisi bisa diangap sebagai simbol kebangkitan masyarakat sipil dalam memperjuangkan kepentingan dan hak-haknya. Masyarakat mulai kritis dan mampu menampilkan wacana tandingan terhadap wacana dan kebijakan yang disodorkan oleh negara.

Menurut Afiff (2007), isu yang sering diangkat oleh LSM ini diantaranya adalah tentang kepastian akan akses dan kontrol terhadap lahan dan sumberdaya hutan. Masalah kepastian tenurial banyak dipersoalkan karena mayoritas dari kawasan kelola masyarakat seringkali tumpang tindih dengan kawasan yang diklaim oleh negara sebagai kawasan hutan.

Tumbuhnya perhatian, pengakuan, dan dukungan dari para peneliti dan aktivis LSM terhadap pola-pola PHBM merupakan satu gejala positif. Paling tidak semua itu telah membuka wawasan dan harapan baru bagi terwujudnya sistem PHBM yang berkelanjutan di masa yang akan datang, yang akan mampu menggantikan pola pengelolaan yang sangat exploitatif selama ini (Lubis, 2000). 
LSM juga dituntut untuk dapat mengembangkan inisiatif lokal dalam mempromosikan pemanfaatan dan penggunaan hutan secara berkelanjutan dan inisiatif lainnya untuk mengembangkan ekonomi lokal yang akan memberikan nilai tambah terhadap komunitas yang hidupnya bergantung pada hutan. Pada saat yang sama inisiatif ini juga diharapkan menjaga pemanfaatan lestari dari sumberdaya hutan (Abidin, 2004b).

Secara umum, banyak LSM yang belum mempunyai sistem penilaian kinerja yang sifatnya menyeluruh. LSM biasanya hanya melakukan evaluasi terhadap audit keuangan beserta aktifitasnya berdasarkan proyek yang telah dilaksanakan. Penelitian ini difokuskan pada beberapa LSM yang mendapatkan dana dari Program Pembangunan Perserikatan Bangsa-Bangsa (United Nations Development Programmel UNDP) yang didukung oleh Komisis Eropa (European Commission/EC) melalui program Pendanaan Kecil untuk Menunjang Pelestarian Hutan Tropis di Indonesia (Small Grants Programme for Operations to Promote Tropical Forest/SGP PTF) di Indonesia pada periode 2005-2007. Melalui program ini telah diberikan sejumlah dana kepada 25 LSM yang tersebar di wilayah Jawa, Sumatera dan Sulawesi Tengah. Tema utama SGPPTF ini adalah pengelolaan sumberdaya hutan berbasis masyarakat yang terpadu. Untuk itu, penelitian ini akan melakukan analisis penilaian kinerja yang menyeluruh terhadap beberapa LSM dalam program pengembangan PHBM yang menjadi mitra SGP PTF UNDP.

\section{Perumusan Masalah}

Kerusakan hutan yang cenderung meningkat dan kebijakan pemerintah yang tidak mendukung terwujudnya kelestarian sumberdaya hutan, mendorong terjadinya perubahan paradigma dari state-based forest management (pengelolaan hutan berbasis negara) keparadigma PHBM.
Dalam pelaksanaan PHBM ini, masyarakat mengalami kendala. LSM sebagai lembaga pendorong dan agen perubahan berupaya membantu masyarakat menuju tujuan PHBM lestari dan masyarakat sejahtera. Berkaitan dengan kondisi tersebut, maka rumusan masalah pertama adalah bagaimana peran LSM dalam program PHBM?

Program yang dilakukan LSM mempunyai keragaman metode, pendekatan, dan sebaran yang berbedabeda. Pendampingan ini juga bersentuhan dengan pemerintah dan pihak-pihak lainnya. Terkait dengan kondisi tersebut, maka rumusan masalah kedua adalah bagaimana strategi peningkatan peran LSM dalam program PHBM di Indonesia?

\section{Tujuan Penelitian}

Tujuan pada penelitian ini adalah, sebagai berikut:

1. Mengkaji dan menganalisis peran LSM dalam pelaksanaan program PHBM.

2. Merumuskan strategi peningkatan peran LSM dalam pelaksanaan program PHBM di Indonesia.

\section{TINJAUAN PUSTAKA}

\section{Karakteristik Lembaga Swadaya Masyarakat}

Istilah LSM di Indonesia sesungguhnya adalah pengganti istilah non-govermental organization (NGO) atau Ornop. Mengutip Salamon dan Anheier, dalam Hadiwinata (2003) mendefinisikan LSM mempunyai ciri-ciri sebagai berikut: (1) Formal, artinya secara organisasi bersifat permanen, mempunyai kantor dengan seperangkat aturan dan prosedur; (2) Swasta, artinya kelembagaan yang berada di luar atau terpisah dari pemerintah; (3) Tidak mencari keuntungan, yaitu tidak memberikan keuntungan (profit) kepada direktur atau pengurusnya; (4) Menjalankan 
organisasinya sendiri (self-governing), yaitu tidak dikontrol oleh pihak luar; (5) Sukarela (voluntary), yaitu menjalankan derajat kesukarelaan tertentu;

Nonreligius, artinya tidak mempromosikan ajaran agama; dan (7) Nonpolitik, yaitu tidak ikut dalam pencalonan dipemilu.

Lebih lanjut menurut Fakih (1996), Ornop dapat digolongkan menjadi tiga tipologi, yaitu: (1) Tipe konformis. Ornop ini bekerja berdasarkan paradigma bantuan karikatif yang berorientasi pada proyek dan bekerja sebagai organisasi yang menyesuaikan diri dengan sistem dan struktur yang ada; (2) Tipe reformis. Ornop ini bekerja didasarkan pada ideologi modernisasi dan developmentalism serta menekankan pada partisipasi rakyat dalam pembangunan; (3) Tipe transformatif. Ornop ini berusaha menemukan paradigma alternatif yang akan mengubah struktur dan suprastruktur yang menindas rakyat serta membuka kemungkinan bagi rakyat untuk mewujudkan potensi kemanusiaannya.

Wirasapoetra (2004) menjelaskan bahwa ada beberapa pendorong tumbuhnya LSM di Kalimantan Timur berdasarkan pengamatan selama 20 tahun terakhir ini. Pertama, LSM yang tumbuh atas dasar kepedualian terhadap kondisi masyarakat dan lingkungan hidup yang memperoleh perlakukan tidak adil oleh rezim Orde Baru. Kedua, LSM yang tumbuh atas dasar kepedulian terhadap kondisi masyarakat dan alam, atau sebagai tindak lanjut dari program terdahulu yang menghasilkan ikatan kerjasama antar pesertanya. Ketiga, LSM yang tumbuh atas dasar hasil kolaborasi beberapa LSM untuk menangani masalah secara spesifik.

\section{Praktik Pengelolaan Hutan Berbasis Masyarakat di Indonesia}

Menurut Suharjito (2006), Pengelolaan Hutan Berbasis Masyarakat (PHBM) adalah sistem pengelolaan hutan yang dilakukan oleh individu atau kelompok suatu komunitas, pada lahan negara, lahan komunal, lahan adat atau lahan milik (individual/rumah tangga) untuk memenuhi kebutuhan individu/ rumah tangga dan masyarakat, serta diusahakan secara komersial ataupun sekedar untuk subsistensi.

Keragaman PHBM di Indonesia menunjukkan variasi berdasarkan asal-usul prakarsa pengelolaannya, status lahan yang dijadikan areal pengelolaan, fungsi kawasan dari lokasi lahan pengelolaan, jenis produk utama yang diusahakan, dan kelembagaan atau organisasi sosial yang terbentuk (atau dibentuk) sebagai institusi pengelolaan hutan (LEI, 2001).

Ada tiga dimensi institusi yang dikembangkan dalam konteks pengelolaan dan pemanfaatan hutan yang berbasis masyarakat, yaitu pengembangan institusi yang terkait dengan pengaturan tata kuasa dan tata guna lahan, pengembangan institusi yang terkait dengan tata produksi, dan pengembangan institusi yang terkait dengan tata konsumsi. Upaya dan strategi pengembangan institusi di tingkat lokal ini pada dasarnya dipengaruhi oleh sedikitnya tiga hal utama yaitu kondisi fisik dan sumberdaya alam setempat, faktor-faktor ekonomi politik pada tingkat internasional, nasional, maupun daerah, dan faktor dinamika sosial politik lokal (Tim Karsa, 2007).

Social Forestry (SF) merupakan salah satu kebijakan Pemerintah dibidang kehutanan yang memberikan akses langsung kepada masyarakat dalam mengelola hutan dengan tujuan untuk membangkitkan ekonomi kerakyatan dan meningkatkan kesejahteraan masyarakat desa di sekitar hutan. Perguliran kebijakan SF ini membuktikan bahwa pemerintah telah melakukan koreksi yang selama ini memposisikan masyarakat sekitar hutan termarjinalkan dengan melatakkan paradigma pembangunan kehutanan berbasis pemberdayaan masyarakat (Departemen Kehutanan, 2005). Tantangan terbesar dalam upaya partisipatif adalah 
ketidakmampuan pelaksana upaya-upaya tersebut dalam menghadapi tuntunantuntunan yang beragam atas hutan melalui kolaborasi (Kusmanto, 2006).

\section{Faktor-Faktor yang Mempengaruhi Kinerja LSM}

Pengukuran kinerja adalah tindakan pengukuran yang dilakukan terhadap berbagai aktivias dalam rantai nilai yang ada pada perusahaan. Hasil pengukuran tersebut kemudian digunakan sebagai umpan balik yang memberikan informasi tentang prestasi pelaksanaan suatu rencana dan titik dimana perusahaan memerlukan penyesuaian atas aktivitas perencanaan dan pengendalian. Pengukuran merupakan suatu cara memantau dan menelusuri kemajuan tujuan-tujuan strategis.

Berdasarkan Ibrahim (2004), kalangan donor menilai bahwa LSM akan dinilai dari empat hal yang masing-masing tidak bisa diabaikan dan saling berkaitan, yaitu dari aspek manajemen teknis, legitimasi, akuntabilitas dan transparansi LSM. Ada tiga indikator yang dapat dijadikan ukuran apakah LSM mempunyai legitimasi. Pertama, pengakuan, apakah LSM diakui keberadaannya oleh pemerintah atau pihak lain yang melibatkannya dalam proses penyusunan kebijakan. Kedua, pembenaran, apakah kegiatan-kegiatan LSM mendapat sambutan dari masyarakat dengan memberikan dukungan moral. Ketiga, dukungan, apakah LSM memperoleh bantuan berupa dana, tenaga, dan sebagainya dari masyarakat maupun pihakpihak lainnya (Ibrahim, 2004).

Secara umum keberadaan setiap organisasi cenderung untuk melakukan pengukuran kinerja yang diharapkan untuk menjawab akuntabilitas organisasinya. Menurut Santika (2004), pada kenyataannya paling tidak terdapat lima aspek yang sangat umum untuk mengetahui kinerja dari suatu organisasi, yaitu aspek finansial, operasi kegiatan internal, kepuasan staf, kepuasan komunitas dan shareholders/stakeholders, dan dimensi waktu. Aspek-aspek inilah yang dapat digunakan untuk mengukur kinerja dan akuntabilitas LSM di Indonesia.

Lebih lanjut Kas (2005) menjelaskan bahwa ada dua aspek penting yang menjadi pokok perhatian dalam melakukan monitoring dan evaluasi untuk mendorong transparansi dan akuntabilitas LSM. Pertama, aspek organisasi, yang meliputi visi dan misi, struktur organisasi, pola pengambilan keputusan, keberlanjutan program, keadilan dan kesetaraan gender, dan pengelolaan keuangan. Kedua adalah aspek program, yang meliputi perencanaan dan pelaksanaan, monitoring dan evaluasi keberlanjutan program, serta sasaran pertanggungjawaban.

\section{Kerangka Pemikiran}

Permasalahan mendasar yang terjadi di dunia kehutanan diantaranya adalah kerusakan sumberdaya hutan yang tinggi sementara kapasitas masyarakat yang tinggal di dalam dan di sekitar hutan masih rendah. Salah satu penyebab adanya kerusakan hutan yang begitu tinggi disebabkan oleh kegagalan kebijakan kehutanan yang tidak berpihak pada masyarakat dan juga tidak berpihak pada kelestaraian sumberdaya hutannya itu sendiri. Kondisi ini kemudian memunculkan banyak inisiatif dalam pengelolaan hutan khususnya pengelolaan hutan yang dilakukan oleh masyarakat.

Beberapa tahun terakhir telah terjadi perubahan paradigma pengelolaan hutan yang dilakukan oleh masyarakat. Pengelolaan Hutan Berbasis Masyarakat (PHBM/community-based forest management) menjadi salah satu pilihan dalam sebuah sistem pengelolaan hutan yang berbasis masyarakat menuju pengelolaan hutan yang lestari. Seiring dengan perubahan tersebut, banyak LSM yang terlibat aktif dan intensif dalam mendampingi masyarakat menuju pengelolaan hutan yang berbasis 
masyarakat. Pengembangan kapasitas dan penguatan kelembagaan masyarakat di sekitar hutan telah menjadi agenda utama dari banyak LSM Kehutanan.

Dalam penelitian ini, indikatorindikator penilaian kinerja yang dikembangkan oleh Yayasan Tifa (2006) akan dijadikan sebagai acuan dalam melakukan penilaian kinerja LSM. Ukuran kinerja akan menilai enam elemen utama, yaitu elemen Visi dan Misi, elemen Program, elemen Tata Laksana, elemen Administrasi, elemen Keuangan, dan elemen Legitimasi. Melalui indikator ini dapat ditentukan tindakan-tindakan yang diperlukan untuk melakukan peningkatan kapasitas lembaga hingga bisa menjadi sebuah lembaga yang mempunyai kinerja lebih baik.

Untuk melihat peran LSM dalam program PHBM terkait dengan pendekatan dengan masyarakat, dilakukan metode analisis pengembangan institusi lokal (Afiff, 2007). Ada empat dimensi institusi yang dikembangkan dalam konteks pengelolaan dan pemanfaatan PHBM, yaitu: (1) pengaturan tata kuasa dan (2) tata guna lahan, (3) pengaturan tata produksi, dan (4) pengaturan tata konsumsi.

Untuk itu, penelitian ini mempunyai nilai penting dalam merumuskan pengembangan strategi dan program LSM Kehutanan dalam pengembangan PHBM di Indonesia melalui penilaian peran LSM sebagai lembaga yang bersentuhan langsung dengan masyarakat dan hutannya. Karena peran LSM sangat penting dalam konteks pendampingan dan advokasi, maka bila kinerja LSM baik dan selalu meningkat maka harapannya akan menuju tujuan utama yaitu pengelolaan sumberdaya hutan berbasis masyarakat yang lestari dan masyarakat sejahtera. Pada Gambar 1 dapat dilihat kerangka pemikiran penelitian penilaian kinerja LSM dalam program PHBM.

\section{METODE PENELITIAN}

\section{Lokasi dan Waktu Penelitian}

Penelitian ini difokuskan pada beberapa LSM yang mendapatkan dana dari Program Pembangunan Perserikatan Bangsa-Bangsa (United Nations Development Programme/UNDP) yang didukung oleh Komisi Eropa (European Commission/EC) melalui program SGPPTF di Indonesia pada periode 20052007. Pemilihan responden terpilih didasarkan pada beberapa kriteria diantaranya adalah pola pendampingan oleh LSM Kehutanan yang bersentuhan langsung dengan masyarakat sekitar hutan; mengangkat isu konservasi, pendampingan teknis (technical assistant), dan advokasi; isu yang diangkat bersifat khas dan fokus pada isu lokalitas, dan wilayah kerjanya berada di hutan negara dan/atau hutan milik.

Pemilihan sampel ini diambil melalui metode stratified sampling yang artinya mengelompokkan populasi ke dalam beberapa kelompok yang lebih kecil, kemudian disampel secara acak dari kelompok-kelompok tersebut untuk kategori konservasi, pendampingan teknis, dan advokasi masing-masing sebanyak tiga LSM. Jumlah sampel yang dipilih adalah sebanyak sembilan LSM yang tersebar di Jawa Tengah, Jawa Timur, Jawa Barat, dan Lampung (Tabel 1). Penelitian ini dilaksanakan pada bulan NovemberDesember 2008. 


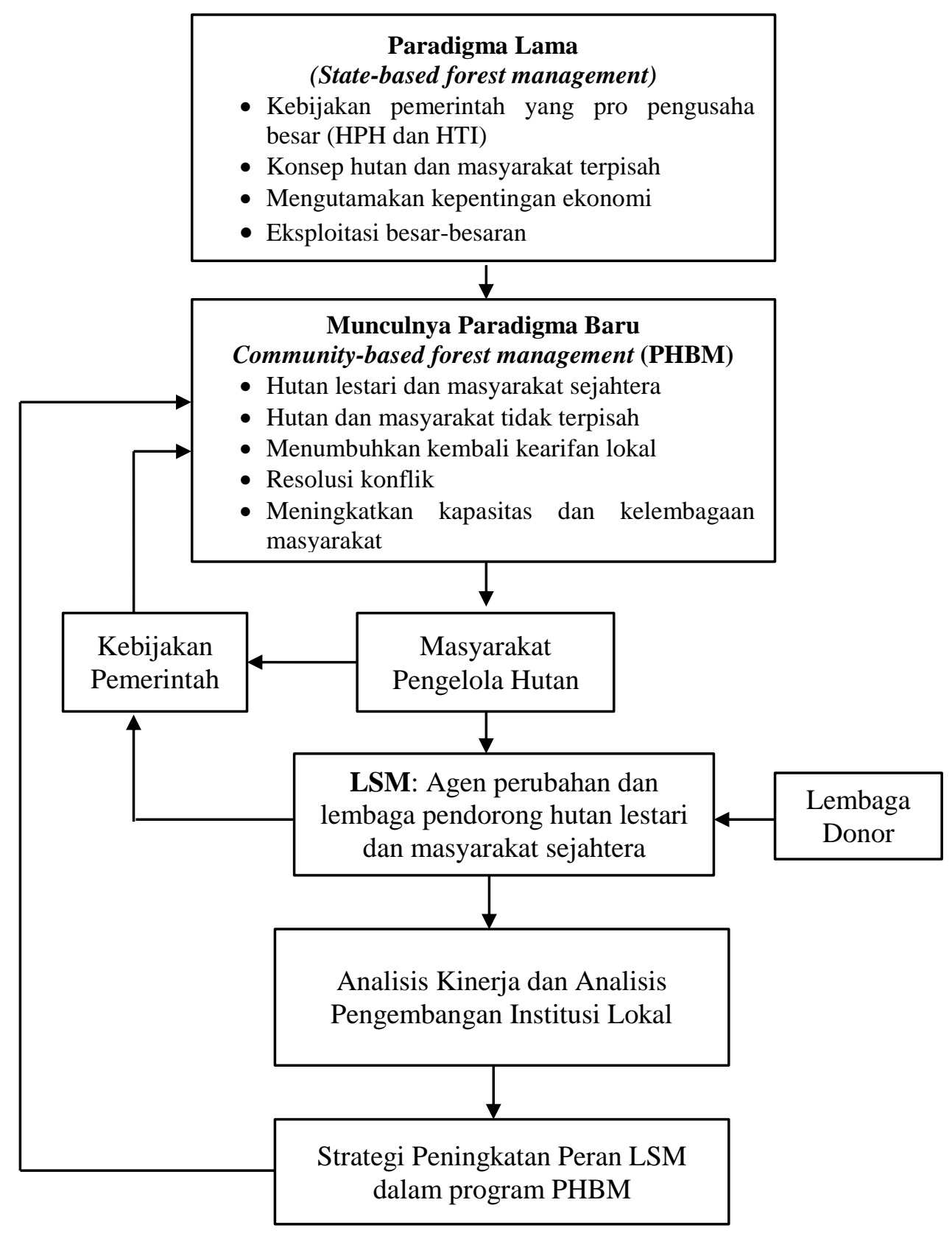

Gambar 1. Kerangkan Pemikiran Penelitian 
Tabel 1. Identifikasi LSM Kehutanan yang Menjadi Fokus Penelitian

\begin{tabular}{|c|c|c|c|c|}
\hline No & Isu Pokok & Nama LSM & Wilayah & Fokus Proyek \\
\hline 1 & & LPPSP & Jawa Tengah & Konservasi di sabuk hijau mangrove \\
\hline 2 & Konservasi & Lembah & Jawa Timur & Konservasi di lahan milik dan hutan lindung \\
\hline 3 & & Mitra Bentala & Lampung & Konservasi mangrove di hutan lindung \\
\hline 4 & & Persepsi & Jawa Tengah & Sertifikasi ekolabel di lahan milik \\
\hline 5 & $\begin{array}{l}\text { Pendampingan } \\
\text { Teknis }\end{array}$ & Paramitra & Jawa Timur & $\begin{array}{l}\text { Pola kemitraan di lahan milik dan hutan } \\
\text { produksi }\end{array}$ \\
\hline 6 & & SHK Lestari & Lampung & $\begin{array}{l}\text { Ekowisata di Taman Hutan Raya Wan } \\
\text { Abdurrahman }\end{array}$ \\
\hline 7 & & YBL Masta & Jawa Tengah & Advokasi tanah simpen di hutan produksi \\
\hline 8 & Advokasi & RMI & Jawa Barat & $\begin{array}{l}\text { Advokasi masyarakat adat di Taman Nasional } \\
\text { Gunung Salak-Halimun }\end{array}$ \\
\hline 9 & & Watala & Lampung & $\begin{array}{l}\text { Advokasi hutan kemasyarakatan di hutan } \\
\text { lindung }\end{array}$ \\
\hline
\end{tabular}

Sumber: Diolah dari proposal 25 LSM yang menjadi mitra SGP PTF - UNDP periode 2005 - 2007

\section{Jenis dan Sumber Data}

Data ini diperoleh dengan melakukan survei kuantitatif dan survei kualitatif. Data kuantitatif diperoleh dari hasil pengisian kuesioner yang diisi oleh LSM Kehutanan. Sedangkan untuk data kualitatif akan dilakukan melalui dua tahap, yaitu: (1) melakukan wawancara dan focus group discussion (FGD) dengan pimpinan dan staf di sembilan LSM Kehutanan terpilih serta melakukan wawancara dengan beberapa tokoh LSM di Indonesia untuk memperkaya data dan informasi, bila diperlukan, (2) melakukan wawancara dan focus group discussion (FGD) dengan masyarakat sebagai kelompok sasaran (target goups) dan penerima manfaat (beneficiaries) dari proyek yang dilakukan oleh sembilan LSM Kehutanan yang mendampingi masyarakat.

Data sekunder diperoleh melalui dua tahap, yaitu: (1) identifikasi fokus proyek dari 25 LSM Kehutanan yang menjadi mitra SGPPTF UNDP periode 2005-2007, (2) melakukan verifikasi dari dokumen-dokumen baik yang dipublikasikan maupun yang tidak dipublikasikan oleh sembilan LSM Kehutanan terpilih.

\section{Metode Analisis}

\section{Analisis Kinerja}

Penentuan elemen kinerja LSM Kehutanan didasarkan pada alat ukur (tools) yang telah dikembangkan oleh Tifa (2006). Tools ini berisi enam elemen yang dapat dijadikan sebagai elemen penilaian kinerja LSM, yaitu: (1) elemen visi-misi dan tujuan, (2) elemen tata laksana (governance), (3) elemen administrasi, (4) elemen program, (5) elemen pengelolaan keuangan, dan (6) elemen legitimasi.

Untuk menentukan bobot terhadap setiap elemen dan indikator kinerja dari masing-masing LSM maka dilakukan dengan penilaian dalam kuesioner. Penentuan bobot dilakukan pada setiap LSM pada lembar penilaian masingmasing dalam sebuah kuesioner. Nilai setiap indikator yang dilakukan pembobotan menunjukkan tingkat pencapaian kinerja LSM tersebut. Setiap LSM akan dinilai berdasarkan tiga skala intensitas atau level untuk setiap indikatornya (Tifa, 2006), yaitu:

1. Level 1 atau Kurang (K), jika setiap indikator yang sedang dinilai belum dapat dipenuhi ataupun potensinya sangat rendah untuk dapat dipenuhi 
dalam jangka waktu yang relatif singkat;

2. Level 2 atau Cukup (C), jika setiap indikator yang sedang dinilai dapat terpenuhi meskipun masih diperlukan sejumlah upaya untuk pemeliharaan dan keberlanjutannya secara tetap dan terus menerus;

3. Level 3 atau Baik (B), jika setiap indikator yang sedang dinilai dapat secara optimal terpenuhi dan menunjukan adanya potensi untuk pemeliharaan dan keberlanjutannya secara tetap atau terus menerus.

Dalam penelitian ini, setiap indikator mempunyai bobot yang sama. Kinerja LSM dinilai dari pembobotan setiap elemen yang diperoleh dengan menentukan nilai setiap indikator terhadap jumlah nilai secara keseluruhan indikator. Penilaian secara menyeluruh ini mengacu pada rumus dalam metode pengambilan keputusan sertifikasi PHBML yang dikembangkan oleh LEI yang diatur dalam Pedoman LEI 99-44 tentang Pedoman Pengambilan Keputusan Sistem Sertifikasi PHBML (LEI, 2001) yaitu:

1. Kinerja yang baik, jika $\mathrm{B} \geq 50 \% \times \mathrm{n}$ dan $\mathrm{C} \geq 25 \%$ x n

2. Kinerja yang cukup baik, jika $\mathrm{B} \geq$ $25 \%$ x n dan $\mathrm{C} \geq 50 \%$ x n

3. Kinerja yang kurang baik, jika selain yang diatas.

dimana:

$\mathrm{B}=$ jumlah indikator yang mendapatkan nilai baik (level 3)

$\mathrm{C}=$ jumlah indiaktor yang mendapatkan nilai cukup (level 2)

$\mathrm{n}=$ jumlah indikator

Penilaian ini akan menentukan bentuk rumusan rekomendasi dan strategi kedepan yang diperlukan bagi peningkatan kinerja setiap LSM. Melalui peningkatan kinerja LSM dalam program pengembangan PHBM diharapkan dapat memberikan dampak positif yang signifikan dan manfaat yang besar bagi PHBM dan masyarakatnya.

Analisis Model Pengembangan Institusi Lokal

Penelitian ini juga menggunakan analisis model pengembangan institusi lokal yang dikembangkan oleh Afiff (2007). Institusi yang dimaksud disini merupakan semua aturan baik formal maupun informal yang digunakan dan dipraktekkan oleh masyarakat di suatu tempat yang terkait dengan pengelolaan dan pemanfaatan hutan. Berdasarkan Afiff (2007), terdapat beberapa dimensi institusi yang dikembangkan dalam konteks pengelolaan dan pemanfaatan hutan yang berbasis masyarakat, yaitu:

1. Pengembangan institusi yang terkait dengan pengaturan tata kuasa tenurial dan tata guna lahan;

2. Pengembangan tata produksi pada tingkat kelompok atau komunitas;

3. Pengembangan tata produksi pada tingkat rumah tangga;

4. Pengembangan institusi yang terkait dengan tata konsumsi.

Upaya dan strategi pengembangan institusi di tingkat lokal pada dasarnya dipengaruhi oleh tiga faktor utama, yaitu: kondisi fisik dan sumberdaya alam setempat; faktor-faktor ekonomi politik pada tingkat internasional, nasional, dan daerah; serta faktor dinamika sosial dan politik lokal.

Pengembangan institusi di tingkat lokal dengan berbagai faktor yang mempengaruhi tersebut bertujuan untuk mencapai pengelolaan lingkungan yang berkelanjutan dan berkeadilan sosial. Untuk lebih jelasnya dapat dilihat pada Gambar 2 dibawah ini. 


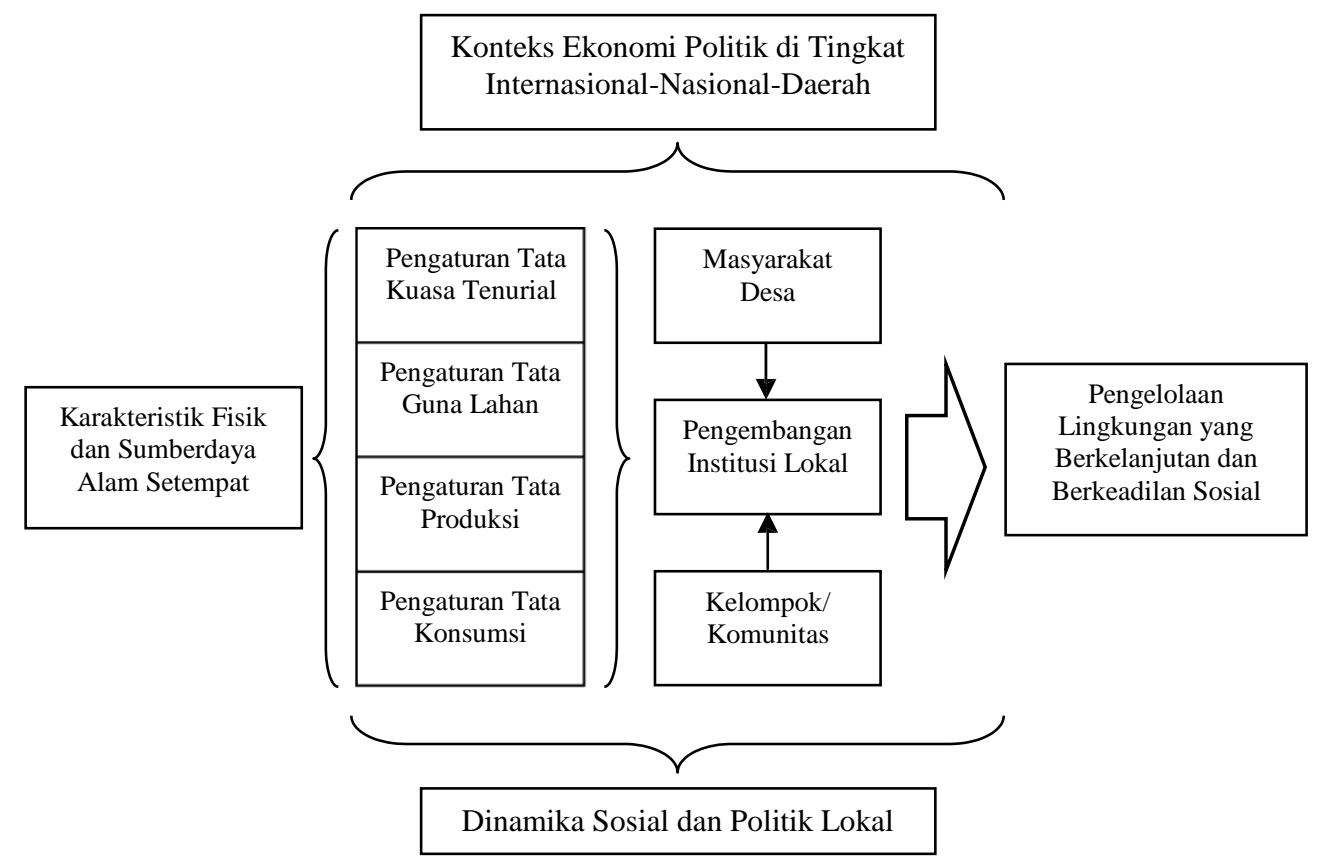

Gambar 2. Kerangka Konseptual Pengembangan Institusi Lokal Sumber: Afiff (2007)

\section{Metode Perancangan Program}

Metode perancangan program yang digunakan adalah melalui pendekatan Logical Framework Approach (LFA). Menurut Tonny (2007), LFA merupakan sebuah alat manajemen dan perencanaan dengan menggunakan teknik visualisasi yang mampu membantu meningkatkan efisiensi dan efektivitas proses perencanaan dan pengelolaan program. Melalui metode ini dapat dirumuskan tujuan-tujuan secara jelas sehingga ikut mendorong tercapainya pengambilan keputusan saat ada pendapat dan harapan berbeda dari stakeholders. Metode ini juga dapat digunakan untuk menyusun informasi secara sistematik serta dapat menghasilkan sebuah rancangan program yang konsisten dan realistis.

\section{HASIL DAN PEMBAHASAN}

\section{Elemen Kinerja LSM dalam Program PHBM}

Pengukuran kinerja adalah tindakan pengukuran yang dilakukan terhadap berbagai aktivitas dalam rantai nilai yang ada pada sebuah lembaga. Hasil pengukuran tersebut kemudian digunakan sebagai umpan balik yang memberikan informasi tentang prestasi pelaksanaan suatu rencana dan titik dimana lembaga tersebut memerlukan penyesuaian atas aktivitas perencanaan dan pengendalian. Pengukuran merupakan suatu cara memantau dan menelusuri kemajuan terhadap tujuan-tujuan yang strategis.

Menurut Tifa (2006), program organisasi senantiasa mengacu pada visi dan misi organisasi. Keterlibatan rekan jejaring dalam perencanaan, pelaksanaan, serta monitoring dan evaluasi program akan sangat membantu tercapainya visi dan misi organisasi. Tanpa program, organisasi tidak akan mempunyai kegiatan, 
karena kegiatan merupakan terjemahan program.

Indikator kinerja merupakan kunci dalam pelaksanaan pemantauan dan evaluasi kinerja. Dalam menyusun indikator kinerja perlu ditentukan sejumlah data yang harus dikumpulkan. Hal ini untuk mengetahui apakah kemajuan pelaksanaan pekerjaan yang telah dilakukan bila dibandingkan terhadap hasil perencanaan yang hendak dicapai dapat terpenuhi (Susanto, 2003).

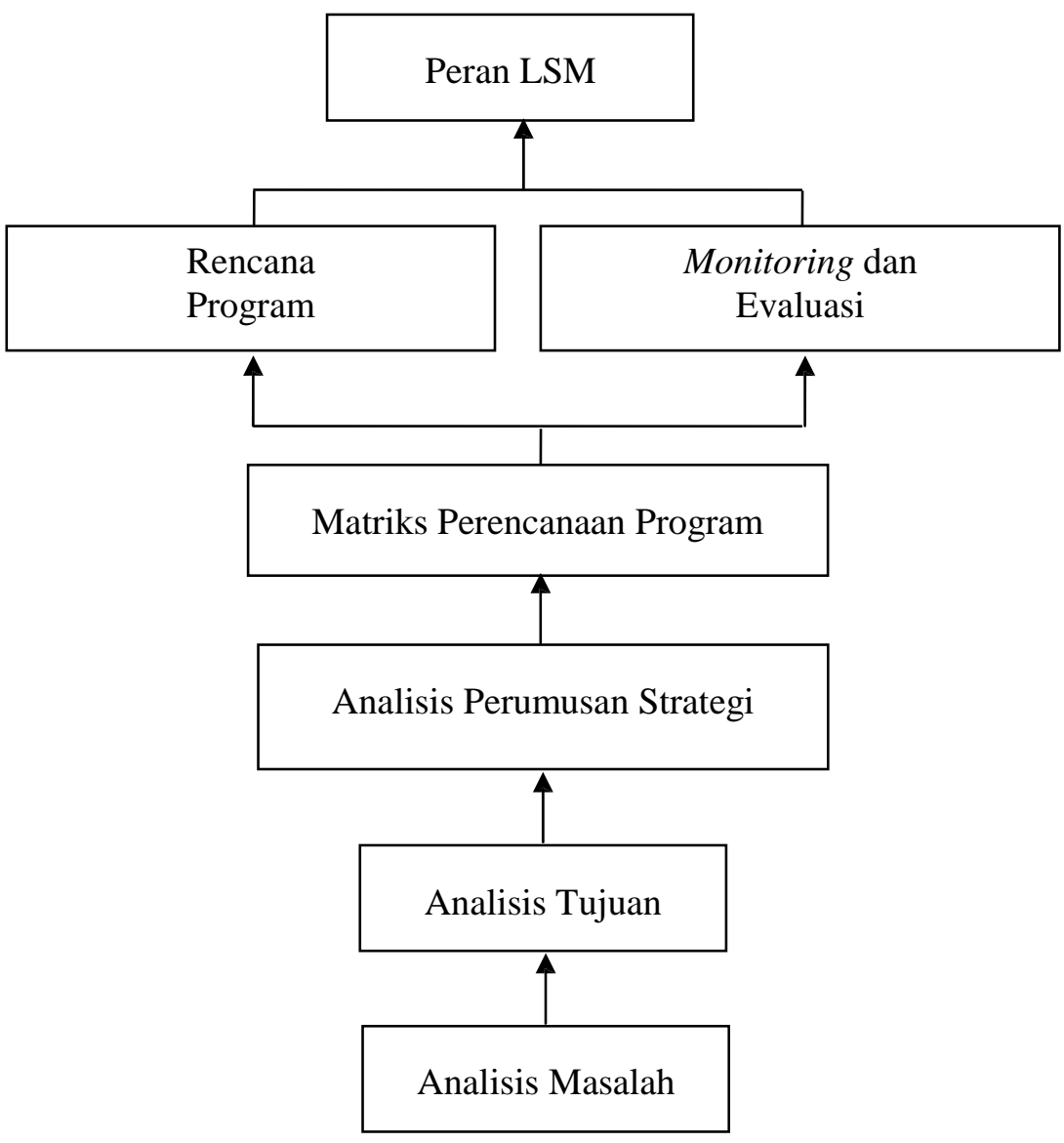

Gambar 3. Diagram Alur Metode Logical Framework Approach (LFA)

Relevansi Visi dan Misi terhadap Program PHBM

Visi adalah cara pandang organisasi terhadap kondisi ideal atau hasil akhir yang ingin dituju. Sedangkan misi adalah alasan/sebab keberadaan organisasi; misi merupakan suatu pola dari sasaran (purpose) yang dapat digunakan untuk mengawali, mengevaluasi, dan merumuskan ulang seluruh kegiatan organisasi. Rumusan misi dianggap baik bila menunjukkan cakupan kegiatan dan masyarakat dampingan (Tifa, 2006).

Dalam penelitian ini, sebagian besar LSM atau sejumlah tujuh LSM menyatakan bahwa orientasi kepentingan organisasi terhadap visi dan misi untuk kepentingan LSM, kelompok dampingan, dan pemangku kepentingan (Tabel 2). Mereka berpendapat bahwa visi dan misi merupakan mimpi dan harapan bersama yang akan diraih pada suatu saat nanti. Tanpa adanya orientasi kepentingan yang jelas, tujuan organisasi akan sulit tercapai. 
Tabel 2. Penilaian Kinerja Elemen Visi dan Misi

\begin{tabular}{|c|c|c|c|c|}
\hline \multirow{2}{*}{ No Indikator } & \multicolumn{3}{|c|}{ Jumlah Nilai Elemen Visi dan Misi } & \multirow{2}{*}{ Total } \\
\hline & Baik & Cukup & Kurang & \\
\hline V.1 Orientasi kepentingan & 7 & 1 & 1 & 9 \\
\hline V.2 Fungsi Visi dan Misi & 4 & 5 & 0 & 9 \\
\hline V.3 Pengalaman dalam Program PHBM & 5 & 4 & 0 & 9 \\
\hline Total & 16 & 10 & 1 & 27 \\
\hline
\end{tabular}

Kesesuaian antara program PHBM dengan fungsi Visi dan Misi ditunjukkan dengan sejumlah lima LSM menyatakan telah sesuai namun visi dan misi yang telah disepakati tersebut belum dijadikan sebagai pedoman atau acuan dalam pelaksanaan program PHBM. Dalam pelaksanaan program PHBM, LSM masih mengandalkan adanya program yang berkembang pada saat itu. Fokus terhadap program PHBM masih belum ditunjukkan oleh sebagian besar LSM.

Namun, sejumlah empat LSM menyatakan telah menyesuaikan antara program PHBM dengan fungsi visi dan misi organisasi dan telah menjadikan visi dan misinya sebagai acuan dalam melaksanakan program PHBM. Hal ini menunjukkan bahwa LSM telah mampu menerjemahkan dengan baik fungsi visi dan misi organisasi ke dalam program PHBM yang dijalankan. Hal ini juga akan berkaitan dengan pengalaman dalam melaksanakan program PHBM yang selama ini dilakukan oleh LSM.

\section{Kinerja Pelaksanaan Program PHBM}

Pelaksanaan program yang dilakukan oleh LSM merupakan jabaran dari misi yang nantinya akan diterjemahkan dalam kegiatan-kegiatan yang lebih operasional. Beberapa hal yang mencakup elemen program diantaranya adalah integritas program, perencanaan program, pelaksanaan program, serta monitoring dan evaluasi. Dalam penelitian ini, pengukuran LSM dilakukan terhadap 15 indikator kinerja LSM dalam melaksanakan program PHBM (Tabel 3).
Hasil penelitian menunjukkan bahwa sebagian besar LSM yaitu empat LSM telah mempunyai kebijakan tentang perencanaan program PHBM yang partisipatif paling tidak selama tiga tahun dan telah diterapkan secara konsisten. Persepsi, misalnya, dalam melakukan perencanaan program diawali dengan penjajagan kebutuhan melalui Participatory Rural Appraisal (PRA) untuk menentukan desain program bersama masyarakat. PRA ini juga bertujuan untuk mengenali faktor-faktor pendukung dan faktor-faktor pembatasnya, serta memetakan peran para pemangku kepentingan dalam pengelolaan hutannya. Menurut Robert Chambers dalam Djohani (2003), PRA merupakan sekumpulan pendekatan dan metode yang mendorong masyarakat (perdesaan) untuk turut serta meningkatkan dan menganalisis pengetahuan mereka mengenai hidup dan kondisi mereka sendiri agar mereka dapat membuat rencana dan tindakan. Dalam konteks penggunaannya, PRA kemudian menjadi metodologi pendekatan program berbasis masyarakat (bottom-up methodology) yang oleh kalangan LSM terus menerus dimodifikasi dan diadaptasi, serta diperkaya metode dan tekniknya, terutama penggunaan metode/tekniknya, baik untuk penjajagan kebutuhan, perencanaan, monitoring dan evaluasi, maupun diskusi topikal (Djohani, 2003). Namun, sejumlah dua LSM masih belum memiliki kebijakan tentang perencanaan program PHBM dalam jangka panjang. Paramitra, misalnya, berdasarkan wawancara, mereka menyatakan bahwa perencanaan ini sebenarnya sudah ada 
namun masih dalam bentuk pemikiranpemikiran diinternal organisasi. Pemikiranpemikiran tentang program PHBM ini belum dapat dituangkan secara tertulis dan belum dilakukan secara partisipasi dengan masyarakat.

Tabel 3. Hasil Penilaian Kinerja Elemen Program

\begin{tabular}{|c|c|c|c|c|c|}
\hline \multirow{2}{*}{ No } & \multirow{2}{*}{ Indikator } & \multicolumn{3}{|c|}{ Jumlah Nilai Elemen Program } & \multirow{2}{*}{ Total } \\
\hline & & Baik & Cukup & Kurang & \\
\hline P.1 & $\begin{array}{l}\text { Kebijakan tentang perencanaan program } \\
\text { PHBM jangka panjang }\end{array}$ & 4 & 3 & 2 & 9 \\
\hline P.2 & $\begin{array}{l}\text { Kebijakan untuk mengintegrasikan proyek } \\
\text { UNDP dengan program lainnya }\end{array}$ & 5 & 3 & 1 & 9 \\
\hline P.3 & Pengalaman lembaga dalam program PHBM & 2 & 2 & 5 & 9 \\
\hline P.4 & $\begin{array}{l}\text { Kebijakan tentang perencanaan program } \\
\text { PHBM jangka panjang yang partisipatif }\end{array}$ & 4 & 4 & 1 & 9 \\
\hline P.5 & $\begin{array}{l}\text { Mendokumentasikan perencanaan dari } \\
\text { proyek UNDP secara sistematis }\end{array}$ & 5 & 2 & 2 & 9 \\
\hline P.6 & $\begin{array}{l}\text { Pelibatan masyarakat dalam menyusun } \\
\text { proposal proyek UNDP }\end{array}$ & 4 & 5 & 0 & 9 \\
\hline P.7 & $\begin{array}{l}\text { Identifikasi dan akses terhadap sumberdaya } \\
\text { dan sumber dana (lainnya) untuk kelanjutan } \\
\text { dari proyek UNDP }\end{array}$ & 5 & 3 & 1 & 9 \\
\hline P.8 & $\begin{array}{l}\text { Kesesuaian perencanaan program dengan } \\
\text { proses pelaksanaan program PHBM }\end{array}$ & 5 & 3 & 1 & 9 \\
\hline P.9 & Pengalaman pelaksana proyek UNDP & 5 & 3 & 1 & 9 \\
\hline P.10 & Manfaat proyek UNDP & 8 & 1 & 0 & 9 \\
\hline P.11 & $\begin{array}{l}\text { Pelibatan stakeholder dalam pelaksanaan } \\
\text { proyek UNDP }\end{array}$ & 5 & 4 & 0 & 9 \\
\hline P.12 & Dampak dari pelaksanaan proyek UNDP & 5 & 3 & 1 & 9 \\
\hline P.13 & $\begin{array}{l}\text { Mekanisme monitoring dan evaluasi yang } \\
\text { partisipatif, baku dan berkala dalam } \\
\text { pelaksanaan proyek UNDP }\end{array}$ & 2 & 2 & 5 & 9 \\
\hline P.14 & Tindak lanjut dari monev proyek UNDP & 7 & 2 & 0 & 9 \\
\hline P.15 & $\begin{array}{l}\text { Hasil evaluasi pelaksanaan proyek UNDP } \\
\text { telah dijadikan sebagai bahan pelajaran }\end{array}$ & 8 & 1 & 0 & 9 \\
\hline & Total & 76 & 40 & 19 & 135 \\
\hline
\end{tabular}

Sebuah kebijakan LSM tentang mengintegrasikan proyek satu dengan proyek lainnya penting untuk dibuat. Sebagian besar (5) LSM menyatakan bahwa mereka memiliki kebijakan internal untuk mengintegrasikan proyek UNDP dengan proyek-proyek atau programprogram lainnya. RMI dan Masta, misalnya, mempunyai sebuah kebijakan internal bahwa setiap program yang berjalan harus disesuaikan dengan rencana program yang telah dilakukan untuk kemudian diintegrasikan dengan program yang sedang berjalan. Strategi ini dilakukan dengan tujuan untuk menghindari adanya tumpang tindih adanya proyek yang dijalankan pada program dan wilayah yang sama. Selain itu, strategi ini juga bertujuan untuk melakukan percepatan pencapaian target yang pada program lain belum dilaksanakan. Keterkaitan antar program 
ini untuk mensinergikan kerja-kerja RMI dan sesuai dengan kebutuhan yang ada di tingkat masyarakat. Sementara itu, satu LSM menyatakan bahwa lembaganya belum memiliki sebuah kebijakan yang mengintegrasikan proyek UNDP dengan program lainnya. Hal ini disebabkan proyek UNDP merupakan satu-satunya proyek yang dilaksanakan selama periode 2005-2007.

$\begin{array}{ccc}\text { Pengalaman } & \text { LSM dalam } \\ \text { melakukan program } & \text { PHBM } & \text { sangat }\end{array}$
beragam. Penelitian ini menemukan bahwa sebelum adanya proyek UNDP, sebanyak lima LSM menyatakan bahwa mereka mempunyai pengalaman bersama masyarakat terlibat dalam proyek PHBM selama 1-3 tahun pada lokasi dimana proyek tersebut dilakukan. Sebelum adanya dukungan dana dari proyek UNDP, RMI, misalnya, menjadikan Kasepuhan Cibedug merupakan lokasi belajar yang relatif baru atas permintaan masyarakat untuk dapat dilanjutkan, dimana sebelumnya merupakan dampak dari kegiatan/program yang dilakukan RMI yang didukung oleh pihak lain. Sebagai satu rangkaian agar permintaan masyarakat untuk difasilitasi RMI dalam memperkuat ruang kelolanya, maka sebelum proyek, RMI berupaya mencari dukungan pendanaan dari lembaga donor seperti Grassroot Fund dan SPARK-VSO untuk melakukan tahapan awal program. Bahkan, Persepsi, baru mendapatkan dana dan memulai pendampingan untuk wilayah dampingan di Sukoharjo melalui proyek UNDP ini, meskipun sebelumnya telah berinteraksi dengan masyarakat namun belum aktif. Hal ini dilakukan karena Persepsi melakukan perluasan (scalling up) program sertifikasi ekolabel setelah sebelumnya berhasil mendampingi masyarakat di wilayah Wonogiri untuk mendapatkan sertifikasi ekolabel dari LEI. Hanya sebagian kecil LSM yaitu sebanyak dua LSM memiliki pengalaman diatas lima tahun. Mitra Bentala dan Watala merupakan LSM yang berpengalaman kurang lebih selama 10 tahun dalam mendampingi masyarakat pada lokasi yang sama dengan proyek UNDP (Tabel 4).

Tabel 4. Pengalaman LSM di Lokasi Proyek dan Fokus Proyek UNDP

\begin{tabular}{|c|c|c|c|}
\hline No & Nama LSM & $\begin{array}{l}\text { Tahun LSM Mulai } \\
\text { Masuk ke Lokasi }\end{array}$ & $\begin{array}{l}\text { Fokus Proyek UNDP } \\
\text { (Periode 2005-2007) }\end{array}$ \\
\hline 1 & LSM 1 & 2000 & Konservasi di sabuk hijau mangrove di pantai Kota Tegal \\
\hline 2 & LSM 2 & 2003 & $\begin{array}{l}\text { Konservasi di lahan milik dan hutan lindung di Pulau } \\
\text { Bawean }\end{array}$ \\
\hline 3 & LSM 3 & 1998 & Konservasi mangrove di hutan lindung di Pulau Pahawang \\
\hline 4 & LSM 4 & 2005 & Sertifikasi ekolabel di lahan milik di Sukoharjo \\
\hline 5 & LSM 5 & 2002 & Pola kemitraan di lahan milik dan hutan produksi di Malang \\
\hline 6 & LSM 6 & 2002 & $\begin{array}{l}\text { Ekowisata di Taman Hutan Raya Wan Abdurrahman, } \\
\text { Lampung }\end{array}$ \\
\hline 7 & LSM 7 & 2004 & Advokasi tanah simpen di hutan produksi di Purworejo \\
\hline 8 & LSM 8 & 2003 & $\begin{array}{l}\text { Advokasi masyarakat adat di Taman Nasional Gunung } \\
\text { Salak-Halimun di Jawa Barat }\end{array}$ \\
\hline 9 & LSM 9 & 1995 & $\begin{array}{l}\text { Advokasi hutan kemasyarakatan di hutan lindung di } \\
\text { Lampung }\end{array}$ \\
\hline
\end{tabular}




\section{Penilaian Kinerja LSM dalam Program PHBM}

Penilaian kinerja LSM dalam Hasil penelitian ini menunjukan bahwa LSM 1 dan LSM 2 mempunyai jumlah total nilai baik yang tinggi yaitu masing-masing sebanyak 88,9 persen dan 72,2 persen (Gambar 4). Sementara LSM lainnya berkisar antara 30-50 persen. Namun LSM enam memiliki jumlah nilai baik yang paling sedikit yaitu sebanyak 16,7 persen dan memiliki nilai kurang baik tertinggi diantara LSM lainnya yaitu sejumlah 36,1 persen. LSM 3 dan LSM 1 bahkan tidak memiliki nilai kurang baik sementara yang lainya memiliki nilai kurang baik berkisar antara 2-30 persen. Keberagaman hasil penilaian kinerja LSM dalam pelaksanaan program PHBM ini menunjukkan bahwa tingkat kapasitas, pengetahuan, dan jaringan yang dikembangkan oleh LSM sangat beragam. Kondisi wilayah, sebaran lokasi pendampingan, metode serta pendekatan yang dilakukan oleh LSM mempengaruhi kinerja LSM yang bersangkutan. Program pokok yang diusung oleh LSM bersama dengan masyarakat juga memberikan pengaruh terhadap kinerja sebuah lembaga dalam proses pendampingan dengan masyarakat.

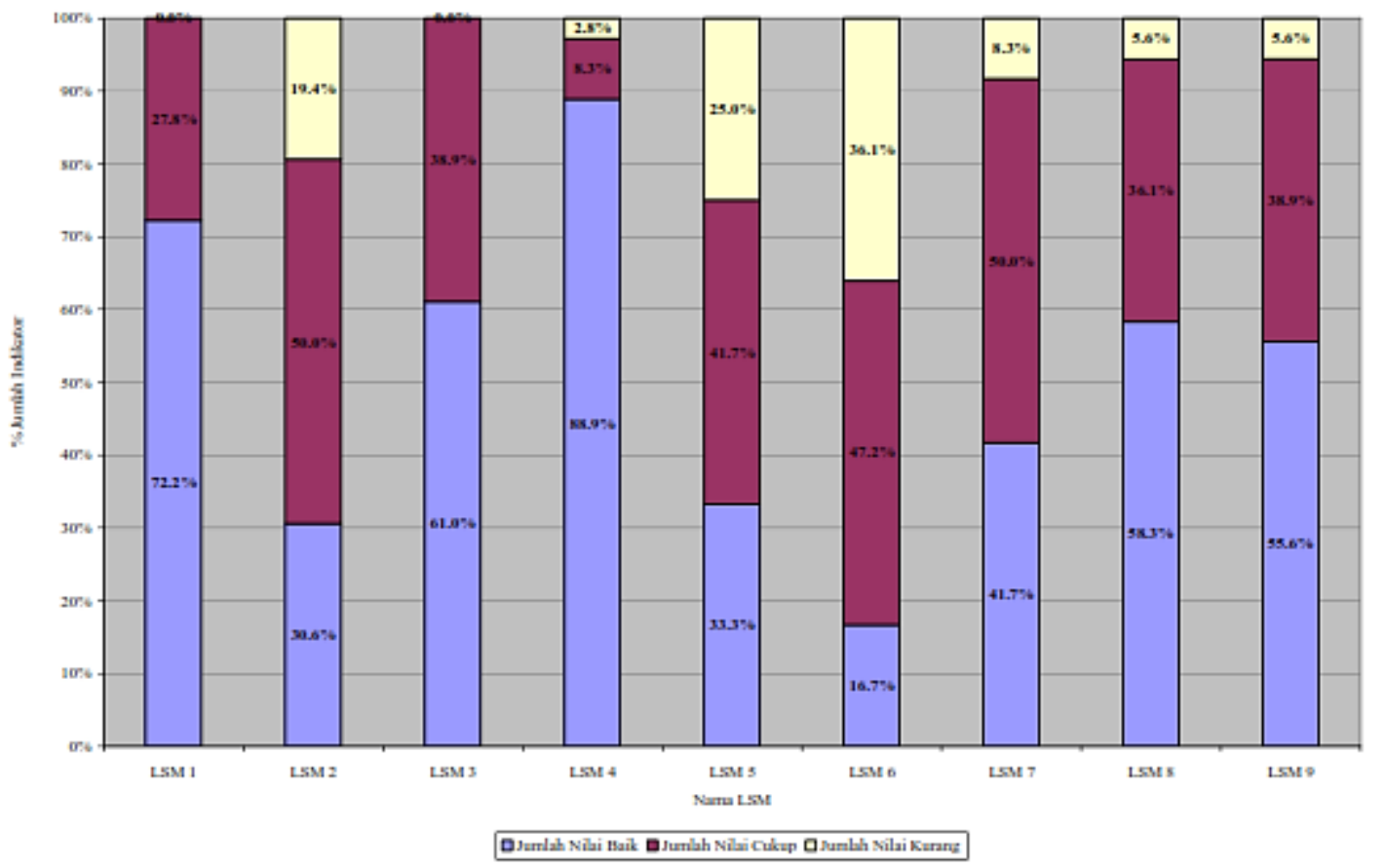

Gambar 4. Rekapitulasi Penilaian Kinerja LSM dalam Program PHBM

Dalam penelitian ini, setiap indikator mempunyai bobot yang sama. Kinerja LSM dinilai dari pembobotan setiap elemen yang diperoleh dengan menentukan nilai setiap indikator terhadap jumlah nilai secara keseluruhan indikator. Jumlah indikator yang digunakan untuk menilai kinerja LSM dalam program PHBM ini berjumlah 36 indikator. Berdasarkan rumus dalam metode pengambilan keputusan sertifikasi PHBML yang dikembangkan oleh LEI, maka:
1. Kinerja yang baik, jika $\mathrm{B} \geq 18$ indikator dan $\mathrm{C} \geq 9$ indikator

2. Kinerja yang cukup baik, jika $\mathrm{B} \geq 9$ indikator dan $\mathrm{C} \geq 18$ indikator

3. Kinerja yang kurang baik, jika selain yang diatas

Berdasarkan rumus tersebut sebagian besar LSM yaitu lima mempunyai kinerja yang baik dalam pelaksanaan program PHBM dan sebanyak dua LSM masing-masing memiliki kinerja yang cukup baik dan kurang baik. 


\section{Analisis Pengembangan Institusi Lokal}

Berdasarkan hasil analisis terhadap penelitian ini, diperlukan beberapa strategi peningkatan peran LSM dalam pembangunan daerah yang berkaitan dengan pengembangan program PHBM. Beberapa strategi yang dapat dilakukan dan dikembangkan oleh LSM dalam program PHBM diantaranya adalah:

1. Pengembangan Kapasitas dan Kelembagaan LSM

2. Pengembangan Pemberdayaan Kapasitas dan Kelembagaan Masyarakat Dampingan

3. Pengembangan Advokasi pada Pemerintah Daerah

4. Pengembangan Usaha Masyarakat Dampingan bersama Pihak Swasta

\section{Rancangan Program Peningkatan Peran LSM dalam Program PHBM}

Berdasarkan hasil analisis dan pembahasan terhadap peran LSM dalam program PHBM, maka dapat dirumuskan beberapa prioritas program strategis berdasarkan analisis LFA yang dapat dilakukan oleh beberapa pihak, diantaranya adalah masyarakat, LSM, pemerintah, dan swasta.

Tujuan utama dari program ini adalah untuk meningkatkan peran LSM dalam pelaksanaan program PHBM di Indonesia. Indikator dari tujuan ini adalah meningkatnya kinerja dan dan peran LSM dalam pelaksanaan program PHBM. Sementara alat verifikasi yang dapat dilakukan adalah meningkatnya kinerja LSM, meningkatnya kesejahteraan masyarakat, meningkatnya kelestarian sumberdaya hutan, serta meningkatnya hubungan yang sinergi antara masyarakat, LSM, swasta dan pemerintah. Asumsi dalam melaksanakan program ini adalah adanya kebijakan pengelolaan hutan berbasis masyarakat yang adil dan lestari serta tidak terjadi gejolak sosial politik yang mempengaruhi kinerja program.

\section{KESIMPULAN DAN SARAN}

\section{Kesimpulan}

1. Sebagian besar (5 LSM) mempunyai kinerja yang baik dalam pelaksanaan program PHBM yang didanai UNDP dan sebanyak dua LSM masingmasing memiliki kinerja yang cukup baik dan kurang baik.

2. Pengembangan institusi lokal dipengaruhi oleh faktor kondisi sumberdaya lokal, faktor ekonomipolitik internasional, nasional dan lokal, serta faktor sosial-politik lokal.

3. Strategi peningkatan peran LSM dalam pelaksanaan PHBM dalam konteks pembangunan daerah dapat dilakukan melalui beberapa hal, yaitu pengembangkan kapasitas dan kelembagaan LSM, pengembangan pemberdayaan kapasitas dan kelembagaan masyarakat dampingan, pengembangan advokasi pada pemerintah daerah, dan pengembangan usaha masyarakat dampingan bersama pihak swasta.

\section{Saran}

1. LSM perlu meningkatkan basis pengetahuan dasar, pemahaman, dan kompetensi dalam program PHBM.

2. LSM perlu menyusun dan mengembangkan instrumen evaluasi kinerja dari pelaksanaan programprogramnya.

3. Lembaga Donor perlu meningkatkan perhatian pada peran LSM dan pemerintah daerah dan perlu membuat strategi keberlanjutan program.

4. Pemerintah perlu membuat kebijakan mendukung hutan lestari \& masyarakat sejahtera. 


\section{DAFTAR PUSTAKA}

Abidin, Hamid ; Mimin Rukmini (editor). 2004a. Kritik dan Otokritik LSM : Membongkar Kejujuran dan Keterbukaan Lembaga Swadaya Masyarakat Indonesia. Piramedia, Jakarta.

2004b. Akuntabilitas dan

Transparansi LSM : Problem dan Ikhtiar dalam Abidin, Hamid ; Mimin Rukmini (editor). Kritik dan Otokritik LSM : Membongkar Kejujuran dan Keterbukaan Lembaga Swadaya Masyarakat Indonesia. Piramedia, Jakarta.

Afiff, Suraya dan R. Yando Zakaria (eds). 2007. Hutan dan Masyarakat: Mendorong Pengelolaan Hutan oleh Rakyat. KARSA kerjasama dengan SGPPTF UNDP - EC SEAMEO. Yogyakarta.

Brown, T. 2004. Analisys of Population and Poverty in Indonesia's Forest. Draf. Natural Resources Management Program Report, Jakarta in Wolenberg, Eva dkk. 2004. Mengapa kawasan hutan penting bagi penanggulangan kemiskinan di Indonesia? Governance Brief, Desember 2004, Nomor 4 (i).

Departemen Kehutanan. 2005. Kumpulan Laporan Studi Lapang PraktikPraktik Social Forestry. Direktorat Bina Hutan Kemasyarakatan, Direktorat Jenderal Rehabilitasi Lahan dan Perhutanan Sosial, Departemen Kehutanan bekerjasama dengan The Ford Foundation.

Departemen Kehutanan. 2007. Data Statistik Kehutanan Tahun 2007. Badan Planologi

Kehutanan, Departemen Kehutanan. Jakarta.

Djohani, Rianingsih. 2003. Partisispasi, Pemberdayaan, dan Demokrastisasi Komunitas: Reposisi Participatory Rural Appraisal (PRA) dalam
Program

Pengembangan

Masyarakat. Studio Driya Media untuk Konsorsium Pengembangan Masyarakat Nusa Tenggara (KPMNT). Bandung.

Fakih, Mansour. 1996. Masyarakat Sipil untuk Transformasi Sosial : Pergolakan Ideologi LSM Indonesia. Pustaka Pelajar, Yogyakarta.

FWI/GFW. 2001. The state of the forest : Indonesia. Bogor, Indonesia : Forest Watch Indonesia and Washington D.C. : Global Forest Watch.

Hadiwinata, B.S. 2003. The Politics of NGOs in Indonesia: Developing Democracy and

Managing a Movement. London. Routhedge Curzon.

Ibrahim, Rustam ; Abdi Suryaninghati ; Tom Malik. 2004. Governance dan Akuntabilitas LSM Indonesia. Diterbitkan untuk Pembentukan Kelompok Kerja Akuntabilitas Organisasi Masyarakat Sipil (OMS), Jakarta.

Kas, Bachtiar. 2005. Menuju LSM yang Transparan dan Akuntabel dalam Majalah GALANG, Edisi 2 tahun IV, Desember 2004 - Februari 2005.

Kusumanto, T., E. E. Yuliani., P. Macoun., Y. Indriatmoko., and H. Adnan. 2006. Learning to Adapt: managing Forest together in Indonesia. CIFOR. Bogor.

LEI. 2001. Naskah Akademis Sistem Sertifikasi Pengelolaan Hutan Berbasis Masyarakat

Lestari. Lembaga Ekolabel Indonesia. Bogor.

Lubis, Z. B. 2000. Menyelaraskan Pola dan Ruang Pengelolaan Sumberdaya Milik Komunal.

Seri Kajian Komuniti Forestri. Seri III/Tahun 2, Februari 2000. LATIN. Bogor. 
Malik, Ichsan. 2004. Pasang Surut LSM di Indonesia dalam Dharmawan, HCB (editor). 2004.

Lembaga Swadaya Masyarakat Menyuarakan Nurani Menggapai Kesetaraan. PT Kompas Media Nusantara, Jakarta.

Santika, Adhi. 2004. Akuntabilitas dan Transparansi LSM : Beberapa Sumbangan Pemikiran dalam Abidin, Hamid ; Mimin Rukmini (editor). 2004. Kritik dan Otokritik LSM : Membongkar Kejujuran dan Keterbukaan Lembaga Swadaya Masyarakat Indonesia. Piramedia, Jakarta.

Suharjito, D. 2006. Berbagi Pengalaman Pendampingan Masyarakat Desa dalam Pengelolaan Sumberdaya Hutan. Program Penelitian dan Pengembangan Kehutanan Masyarakat, Fakultas Kehutanan IPB bekerjasama dengan Debut Press Jogjakarta.

Sunderlin, W.D., Resosudarmo, I.A.P., Rianto, E. and Angelsen, A. 2000. The Effect of Indonesia's Economic Crisis on Small Farmers and Natural Forest Cover in the Outher Islands. Occasional Paper 28 (E). Bogor, CIFOR.

Susanto, R.D. 2003. Pemantauan dan Evaluasi Kinerja: Tips Memilih Indicator Kinerja dalam www.bappenas.go.id/index.php?mo dule $=$ filemanager $\&$ func $=$ download\&pathext=contentexpress /\&view $=411 /$. Diakses tanggal 1 desember 2008.

Tim Karsa. 2007. Inisiatif Lokal dalam Mozaik Kehutanan Indonesia. Karsa bekerjasma dengan SGP PTF UNDP-EC-SEAMEO SEARCA. Yogyakarta.

Tonny, Fredian. 2007. Metodologi Kajian Pembangunan Daerah. Bahan Kuliah SEP300.

Manajemen Pembangunan daerah. Sekolah

Pascasarjana, IPB. Bogor
Wirasapoetra, Koesnadi. 2004. Interaksi Donor-donor Kalimantan Timur dalam WACANA Edisi 16, Tahun IV 2004.

Yayasan Tifa. 2006. Mengukur Transparansi dan Akuntabilitas LSM: Suatu Metode Partisipatif. Edisii Revisi. Jakarta. 